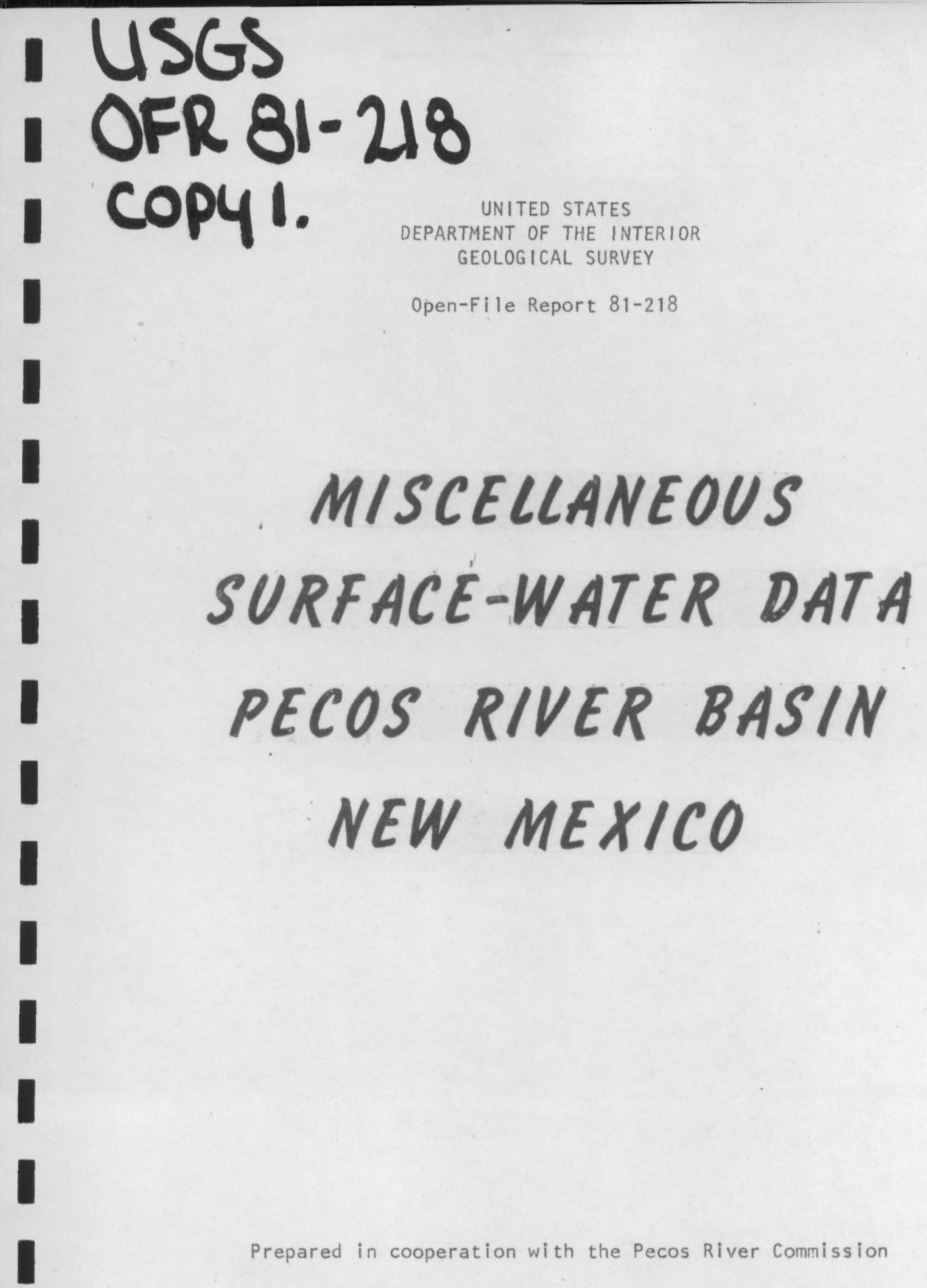


UNITED STATES

DEPARTMENT OF THE INTERIOR

GEOLOGICAL SURVEY

MISCELLANEOUS SURFACE-WATER DATA

PECOS RIVER BASIN, NEW MEXICO

By C. Clare Cranston, Georgianna E. Kues, and G. E. Welder

Prepared in cooperation with

the Pecos River Commission

February 1981 


\section{Contents}

Page

Factors for converting inch-pound units to International

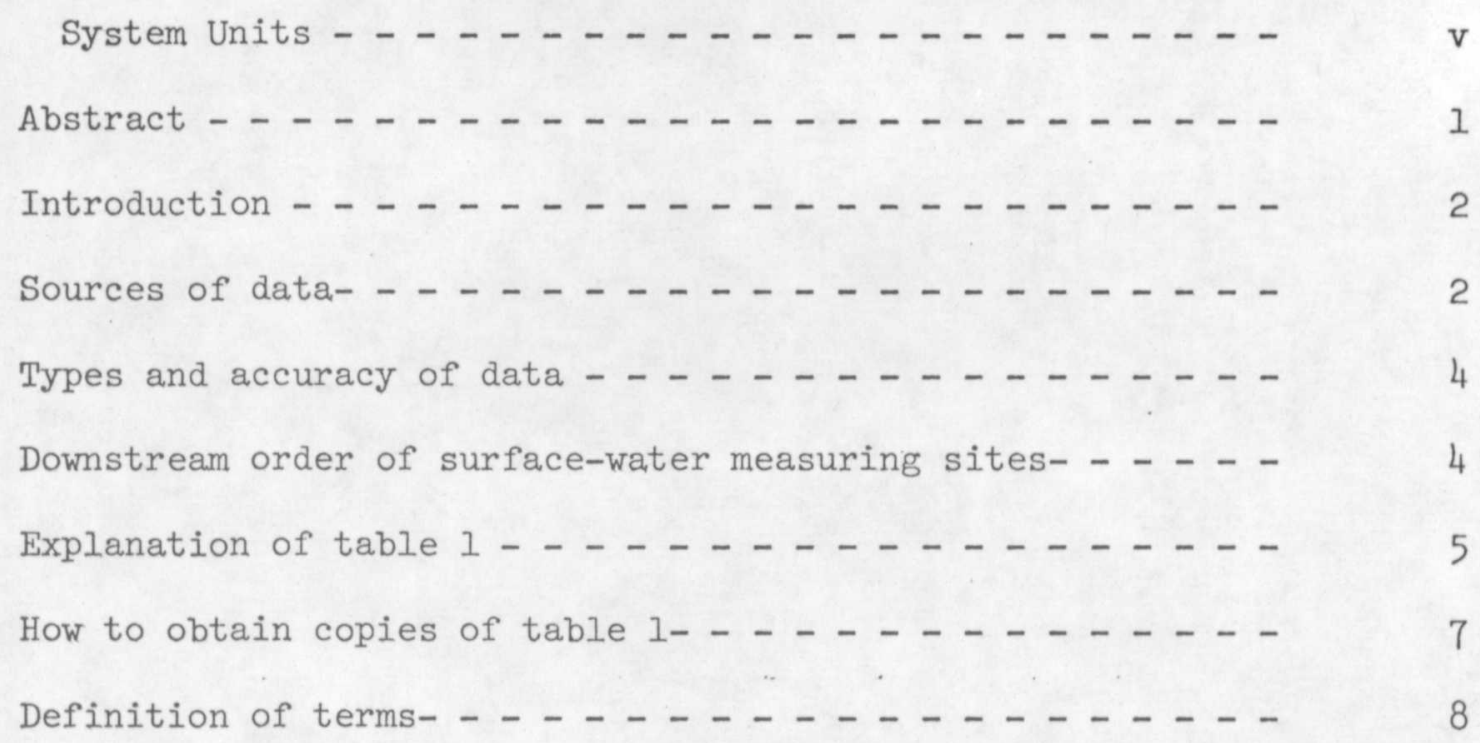


Figure 1.--Map of Pecos River Basin in New Mexico showing locations of key surface-water measuring sites- - In pocket

\section{Table}

Table 1.--Miscellaneous surface-water data, Pecos River Basin, New Mexico- $\ldots \ldots \ldots$ Microfiche in pocket 


\section{Factors for converting inch-pound units to \\ International System Units (SI)}

The following factors may be used to convert the inch-pound units published herein to the International System of Units (SI). This report contains both the inch-pound and SI unit equivalents in the data collection site descriptions of table 1. .

Multiply inch-pound units

feet $(f t)$

miles (mi)

acre-feet (acre-ft)

cubic feet per second $\left(\mathrm{ft}^{3} / \mathrm{s}\right)$
By

$3.048 \times 10^{-1}$

$1.609 \times 10^{0}$

$1.233 \times 10^{3}$

$2.832 \times 10^{-2}$
To obtain SI units

meters (m)

kilometers ( km)

cubic meters $\left(\mathrm{m}^{3}\right)$

cubic meters per second $\left(\mathrm{m}^{3} / \mathrm{s}\right)$ 


\title{
MISCELLANEOUS SURFACE-WATER DATA, \\ PECOS RIVER BASIN, NEW MEXICO \\ by
}

C. Clare Cranston

Georgianna E. Kues and G. E. Welder

\begin{abstract}
Miscellaneous surface-water data from the Pecos River Basin of New Mexico are assembled into one table. Measurements and estimates of the discharge of streams, springs, and diversion canals and pumps that are not readily available to the public are given.

The principal sources of information are published and unpublished reports and various records of the U.S. Geological Survey and the New Mexico State Engineer Office. Many thousands of surface-water discharge values are given.
\end{abstract}


This compilation (table 1 ) of surface-water data lists miscellaneous discharge measurements and estimates of streamflow, streamflow diversions, and springflow in the Pecos River Basin of New Mexico (fig. 1). The purpose of this report is to present surface-water data that have not been readily available in the past. The data can be used by government agencies, private companies, and individuals in making more complete hydrologic analyses of the Pecos River system. This information is of particular interest to the Pecos River Commission, which has cooperated with the Geological Survey in this study, as well as many other studies of the Pecos River Basin in New Mexico. The Commission is responsible for the administration of the Pecos River Compact. The Compact is an agreement between New Mexico, Texas, and the U.S. Government concerning the use of Pecos River water.

\section{Sources of data}

The surface-water data in table 1 were collected by the senior author from a variety of reports and records. These documents were on file in the New Mexico State Engineer Office in Santa Fe, New Mexico, and the Water Resources Division Offices of the U.S. Geological Survey in Albuquerque and Carlsbad, New Mexico, and in Reston, Virginia. Most of the data are miscellaneous measurements of surface-water discharge that were made by the U.S. Geological Survey, the New Mexico State Engineer Office, the U.S. Bureau of Reclamation (now Water and Power Resources Service), and the Carlsbad Irrigation District.

A list of the published reports, unpublished reports, and records from which the data were taken is given below.

I/ Bonstedt, F., and Debler, E. B., 1923, Report on investigations, Pecos River and Carlsbad Project extensions in New Mexico (1920-1923): U.S. Department of the Interior, Reclamation Service, 244 p.

2/ Elder, C. C., 1925, Pecos River Investigations: U.S. Bureau of Reclamation.

3/ Fiedler, A. G., and Nye, S. S., 1933, Geology and groundwater resources of the Roswell Artesian Basin, New Mexico: U.S. Geological Survey Water-Supply Paper 639, 372 p., 37 figs.

If Fogg, P. M., 1914, Report on an investigation of the Pecos River in Texas: U.S. Department of the Interior, Reclamation Service.

2/ Follett, W. W., 1914, Hydrographic survey of the Bonito and Hondo Rivers, and of Eagle Creek, Lincoln County, New Mexico: prepared for El Paso and Rock Island Railway Company, 1913-14.

I/ Good, John M., 1972, Permanent springs of Carlsbad Caverns National Park: unpublished report in the files of the National Park Service, Carlsbad, New Mexico. 
I/ Harroun, P. E., 1898, The present condition of irrigation and water supply in New Mexico; in Report of the Governor of New Mexico to the Secretary of Interior for the fiscal year ended June 30,1898, p. 20-48.

2/ Interstate Stream Commission for New Mexico: miscellaneous records.

2/ Lee, Charles H., 1912, Report of hydrographic conditions on Rio Bonito, Lincoln County, New Mexico

4) Means, T. H., and Gardner, F. D., 1900, A soil survey in the Pecos Valley, New Mexico: U.S. Department of Agriculture Report 64, p. $36-76$.

4f Nettleton, E. S., 1892, Artesian and underflow investigation, final report of the chief engineer: 52d Cong., lst sess., S. Ex. Doc. 41, pt. 2, p. 12-19.

4/ Newell, F. H., 1890, Report on agriculture by irrigation in the western part of the United States, second edition, pp. 193-201.

2/ New Mexico State Engineer Office

1902, Report on irrigation investigations for 1901, p. 37-51.

1909, Irrigation in New Mexico, Bull. 215.

1920-22, Hydrographic survey of Pecos River.

1930-31, Report on the Bonito River hydrographic survey.

1932, Report on the Cottonwood Creek hydrographic survey, Eddy County, New Mexico.

1931, Invisible loss and gain investigation of the Pecos River.

2/ Pecos River watermaster files in New Mexico, miscellaneous records.

2/ Powell, Carlos W., 1954, Supply and uses of the waters of the upper Bonito River and Eagle Creek, Lincoln County, New Mexico.

4/ Reed, W. M., 1900, The use of water in irrigation in the Pecos Valley: U.S. Department of Agriculture Bulletin 86.

If Robinson, T. W., and Lang, W. B., 1938, Geology and ground-water conditions of the Pecos River Valley in the vicinity of Laguna Grande de la Sal; in Twelfth and thirteenth biennial reports of the New Mexico State Engineer, p. 77-100.

If Schuler, James D., 1901, Reservoirs for irrigation, water power, and domestic water supply, first edition, p. 49-58, 363, and 366.

2/ Sullivan, Vernon L., 1924, Pecos River Compact report to Pecos River Commission, p. $7-13,18$.

2/ Territorial Engineer of New Mexico 1907-08, First biennial report.

1908, Hydrographic survey of Black River.

1909, Hydrographic survey of Rio Hondo, 1908-09. 
4/ U.S. Bureau of Immigration, 1894, New Mexico - Its resources, climate, geography, geology, history, statistics, present conditions and future prospects, p. 244-271.

2f U.S. Bureau of Reclamation

1915, Hondo project, Roswell, New Mexico, History from conception of project in Feb. 1904 to Dec. 31, 1915: Vol. I, p. 10-64, Vol. II, p. 7-117.

1904-05, Fourth annual report, Reclamation Service, p. 271-274. 1906-07, Sixth annual report, Reclamation Service, p. 146-151.

3/ U.S. Geological Survey, Water Resources Division, numerous Water Supply and Irrigation Papers.

U.S. Geological Survey, Water Resources Division, numerous unpublished surface-water records in the files of the office in Carlsbad, New Mexico.

2f Wells, H. L., and Atha, R. W., 1920, Hydrographic survey, Pecos River, lower end.

If Published report in files of New Mexico State Engineer Office, Santa Fe.

2/ Unpublished reports and records in files of New Mexico State Engineer Office, Santa Fe.

3/ Published report in Water Resources Division Offices of U.S. Geological Survey in Albuquerque and Carlsbad, New Mexico.

4f Published report in the U.S. Geological Survey library, Reston, Virginia.

Types and accuracy of data

The principal types of surface-water data in this report (table 1) are discharge measurements of streams, springs, and diversions from streams by canals, ditches, and river pumps. The early data were obtained by a variety of devices and methods including current meter, V-notched and rectangular weirs, the area and surface float method, and visual estimates. Indications of where estimates of flows were made and where special methods were used to obtain flows are given in an explanation of footnotes for table 1. (See section of report entitled: "Explanation of Table l".)

\section{Downstream order of surface-water measuring sites}

Maps of the Territorial Engineer, the State Engineer, the U.S. Geological Survey, the State Highway Department, and various maps from hydrologic reports were used to locate the sites where surface-water flows were measured or, in some cases, estimated. All of the measuring sites listed in table $l$ are in 
downstream order. The data-site numbering system starts with the smallest site-index number, which is located near the headwaters of the Pecos River. The site-index numbers increase downstream to above the mouth of a river tributary on which measurements or estimates have been made. At this point the numerical order shifts to the most distant upstream measuring site on the tributary, then progresses down the tributary and back to the Pecos River. The site-index numbering order then continues to increase downstream on the Pecos River until it is again diverted up the next tributary having measuring sites.

The numerical order of the measuring sites is indicated by the index numbers of the key measuring sites shown on figure 1 . Index numbers of sites omitted from figure 1 are inferred.

\section{Explanation of table 1}

Table $I$ is a computer printout of miscellaneous surface-water data collected in the Pecos River Basin of New Mexico. The basic format of table 1 consists of seven columns of data which are labeled, from left to right, as follows: SITE-INDEX NUMBER (SITE IND. \#), STREAM, TRIBUTARY TO, LOCATION, DATE, DISCHARGE VALUE (DISCH. VAL.), TIME.

SITE-INDEX NUMBER.--The SITE-INDEX NUMBER is the identification number of the surface-water measuring site. It is given in downstream order as described in the previous section of this report.

STREAM.--The STREAM column contains the name of the stream on which the surface-water discharge measurement was made.

TRIBUTARY TO.--The TRIBUTARY TO column contains the name of the stream to which the stream listed in the STREAM column is tributary to. The Rio Felix, for example, is a tributary to the Pecos River.

LOCATION.--The first part of the LOCATION column gives the location of. the measuring site by latitude and longitude, and by township, range, and section.

In addition, many of the location descriptions contain a river-mile designation, which was measured on U.S. Geological Survey topographic maps in an upstream direction from the New Mexico-Texas State line. The river-mile is the distance along the center of the normal flow channel of the Pecos River and tributaries. The New Mexico-Texas State line is considered to be 402.4 river-miles upstream from the mouth of the Pecos River where it enters the Rio Grande in Texas. To obtain the river-mile distance in New Mexico of measuring sites upstream from the Texas boundary, subtract 402.4 from the river-mile given for the site.

Many of the measuring-site location descriptions contain a statement concerning the distance of the site from the mouth of a tributary or some fixed landmark. All of the location-related distances in table 1 are given in miles or feet and kilometers or meters. 
DATE.-The DATE column contains the month, day, and year that a measurement was made. Dates showing 00 day and/or 00 month followed by the year are for mean monthly or annual discharge values.

DISCHARGE VALUE.--The DISCHARGE VALUE column generally contains discharge values obtained from actual discharge measurements or mean-daily discharge values calculated from continuous recorder charts. In some cases, however, the mean-daily values were estimated from one or more daily readings by observers.

If the total number of discharge values for one measuring site exceeds 21 , the values are arranged in three separate columns with dates and, in some cases, the time of day (see TIME column description). The values are read in rows across the columns from left to right.

If the number of discharge values exceeds 50 for one year, a 12-column calendar-year table is shown. Data values associated with the calendar-year table, such as a hand measurement rather than a recorder derived daily mean or an estimated value, are given below the table with appropriate footnotes (see "Explanation of Footnotes").

The discharge values are given in $\mathrm{ft}^{3} / \mathrm{s}$ (cubic feet per second) unless otherwise noted. Also included in the DISCHARGE VALUE column are some early values of reservoir content and stage of Lake McMillan and of Lake Avalon. Reservoir content is given in acre-ft, and stage is given in feet.

TIME.--The TIME column may or may not contain the "military" time-of-day for the corresponding value in the DISCHARGE VALUE column. Mean-daily discharge values never have a corresponding time-of-day entry, but a time-of-day is generally given for individual discharge measurement values.

If two or more discharge measurement values are given for one day and the actual times of the measurements are not known, then arbitrary times such as 0800,1200 , and 1600 are shown. This will insure that one of the discharge-measurement values is not mistaken for a mean-daily discharge value.

Most mean-daily values are given in the 12-column calendar-year table. Those mean-daily values in the other table formats, however, are listed for three or more consecutive days. Occasionally dischargemeasurement values (not mean-daily) are given in the 12-column calendar table, but the values will be on scattered nonconsecutive days.

An explanation of footnotes to the DISCHARGE VALUE column of table 1 is given below. 


\section{Explanation of Footnotes}

$\begin{array}{ll}* & \text { Measured during period } \\ \text { A } & \text { Discharge, diversion, or volume estimated } \\ \text { B } & \text { Slope-area measurement of peak flow } \\ \text { C } & \text { Water taken into pipeline from North Fork at Rio Bonito } \\ \text { D } & \text { Source of data: W. W. Follett (19l4) } \\ \text { DP } & \text { Damp } \\ \text { E } & \text { Water overflowing to flood plain } \\ \text { F } & \text { Downstream from return of flood-plain overflow } \\ \text { G } & \text { Maximum discharge computed using Kutter's formula } \\ \text { H } & \text { Mean-daily streamflow, diversions, or contents during } \\ & \text { various periods of time exceeding one day } \\ \text { I } & \text { Excess flow from irrigation canal to stream } \\ \text { J } & \text { Source of data: Water and Power Resources Service } \\ & \text { (formerly U.S. Bureau of Reclamation) } \\ \text { K } & \text { Includes flow of E. Fritz ditch (site l44) } \\ + & \text { Undetermined amount of perennial flow } \\ \text { L } & \text { No diversion from stream or canal } \\ \text { M } & \text { No streamflow or diversion during indicated period of time } \\ \text { N or R } & \text { Record unreliable } \\ \text { P } & \text { Peak or maximum streamflow } \\ \text { Q } & \text { Daily average streamflow or diversion } \\ \text { S } & \text { Too much streamflow for measuring device } \\ \text { T } & \text { Streamflow, diversion, or contents in acre-feet } \\ \text { TX } & \text { Trace } \\ \text { U } & \text { Stream dry during irrigation season } \\ \text { V } & \text { Total streamflow or diversion during irrigation season } \\ \text { W } & \text { Combined flow of all diversions } \\ \text { Y } & \text { Measurements at third reservoir site (Damsite 3) } \\ \text { MX } & \text { Maximum } \\ \text { MN } & \text { Minimum }\end{array}$

How to obtain copies of table 1

Paper copies of table 1 may be made from the microfiche film in the pocket of this report. In addition, the file containing table 1 (called TABOUT) is recorded on each of three tapes stored in the Albuquerque District office of the Water Resources Division of the U.S. Geological Survey. One tape, labeled GS80, is available for making printouts of table 1 through the Harris Computer System of the Geological Survey. 
Each of the two other tapes contains complete copies of the TABOUT file of table 1. These tapes, which serve as backup copies for the TABOUT file, have been set up to be compatible with computer installations other than the Geological Survey's Harris System in Albuquerque. These tapes have the following specifications: UNBLOCKED, UNLABELED, ASCII, and 1600 BPI. Exact methods of retrieval for these tapes will vary with the type of installation. If the requestor will supply a blank type, the TABOUT file will be copied onto his tape and returned for use on his particular computer installation. A charge will be made for copying the file on to a tape or making printouts of table 1 .

\section{Definition of terms}

Terms related to surface-water flow and volume as used in this report are defined below. See also the table for converting inch-pound units to the International System of Units near the front of this report.

Acre-foot (Ac-ft, acre-ft)--A quantity of water required to cover one acre to a depth of 1 foot; equivalent to 43,560 cubic feet or about 326,000 gallons or 1,233 cubic meters.

Contents--The volume of water in a reservoir or lake. In this report, reservoir contents may be given in acre-feet or indicated by stage, in feet.

Cubic foot per second (CFS, $\mathrm{ft}^{3} / \mathrm{s}$ )--The rate of discharge representing a volume of 1 cubic foot passing a given point during 1 second; equivalent to 7.48 gallons per second, 448.8 gallons per minute, or 0.02832 cubic meters per second. A CFS-day is the volume of water represented by a flow of 1 cubic foot per second for 24 hours.

Kutter's formula--A formula that expresses the value of the Chezy coefficient in the Chezy equation in terms of the friction slope, hydraulic radius, and a roughness coefficient. The chezy equation was used to compute the velocity of uniform flow in an open channel. Explanations of Kutter's and Chezy's formulas are given in the following: Daugherty, R. L., 1937, Hydraulics - A text on practical fluid mechanics, 4th ed.: New York, McGrawHill Book Co., Inc., 460 p.

Mean-daily discharge--The average discharge in a day that generally is computed by use of a continuous stage recorder.

Miscellaneous measuring site--A location other than continuous or partial record stations where random discharge measurements are made to give better areal coverage of flow events in a river basin.

Stage, gage height--The water-surface elevation referred to some arbitrary gage datum. Gage height is often used interchangeably with the more general term, stage. 
